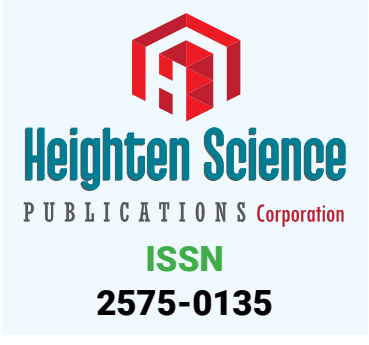

*Address for Correspondence: Rômulo M de Moraes Filho, Pós-Graduação da Universidade Federal Rural de Pernambuco (UFRPE), Brazil, Tel: +55 81 997936198; Fax: Email: romulommfilho@yahoo.com.br

Submitted: 01 February 2018 Approved: 07 February 2018 Published: 08 February 2018

Copyright: @ 2018 de Moraes Filho RM, et al. This is an open access article distributed under the Creative Commons Attribution License, which permits unrestricted use, distribution, and reproduction in any medium, provided the original work is properly cited.

Keywords: Root knot nematodes; Guava; Rootstocks

\title{
Reaction of Psidium guineense and Psidium guajava genotypes to infection of Meloidogyne enterolobii
}

\author{
Rômulo M de Moraes Filho ${ }^{1,2 *}$, Edilton de Albuquerque Cavalcanti \\ Jr. ${ }^{1,2}$, Jackeline Gadé A Rossiter ${ }^{1,2}$, Angélica Virginia Valois \\ Montarroyos $^{1,2}$ and Luiza Suely Semen Martins ${ }^{1,3}$ \\ ${ }^{1}$ Pós-Graduação da Universidade Federal Rural de Pernambuco (UFRPE), Brazil \\ ${ }^{2}$ Departamento de Agronomia, (UFRPE), Brazil \\ ${ }^{3}$ Departamento de Biologia, (UFRPE), Brazil
}

\section{Abstract}

Psidium guajava (guava) is an important crop and economic resource in many tropical countries and Brazil stands out as one of its major commercial producers. The guava crop has been severely attacked by the plant parasitic nematode Meloidogyne enterolobii which has caused drastic reduction of productivity and, in some cases, even total loss of cultivated areas. The use of resistant rootstocks that are tolerant to these soil pathogens can be a low-cost solution to this pathogen, which has established itself as one of the major constraints for the cultivation of guava in Northeast Brazil. The objective of this work was to evaluate the reaction of $P$. guajava and $P$. guineense to $M$. enterolobii infection under greenhouse conditions, with an infection period of 60 days. $12 P$. guineense, and $4 P$. guajava were evaluated. The host response to the nematode infection was evaluated according to the following parameters: gill index (GI), reproductive factor (RF), and reduction of reproductive factor (RRF). Considering the RRF criteria, the $P$. guineense genotypes, AR1, AR3, AR4 and AR10 were considered resistant. The RF index was considered inadequate to evaluate resistance in the 60 days period, due the slow development of the parasite in P.guineense.

\section{Introduction}

The Psidium genus, has approximately 150 species, and is mainly known for the species Psidium guajava L., P. cattleyanum Sabine and P. guineense Swartz (Araçá) [1]. P. guajava (Guava) stands out for its great economic importance in several tropical and subtropical countries, and Brazil is one of its major commercial producers [2]. The economic importance of guava cultivation is due to the high nutritional value of its fruits and the various possible forms of consumption, either in natura or as industrialized products $[3,4]$. Among the species of the Myrtaceae family, P. guajava and $P$. guineense are the most economically important. Although P. guineense does not share the same importance of Guava, this species is of great interest for research and genetic improvement due to desirable characteristics of its fruits, such as high levels of vitamin $\mathrm{C}$, and also the possible resistance to the plant parasitic nematode Meloidogyne enterolobii, which has been decimating guava orchards [5,6]. This situation is aggravated by the low genetic variability of the Brazilian commercial varieties, where approximately $70 \%$ of the orchards are composed by the Paluma cultivar, which is destined for industrialized consumption [7]. M. enterolobii represents a constant danger for cultivated plants. Its rapid dissemination and polyphagic habit, which enables it to live within roots and parasite a large number of species, such as ornamental plants, tobacco, soy, coffee, papaya, acerola, araçá, guava, weeds and various vegetables, make 
it a difficult plague to control [8-11]. To this date, several studies have been carried out to find genotypes of guava resistant to the infection of root-knot nematodes. Psidium species, such as $P$. guineense and $P$. cattleyanum can be a source of resistance, which makes them important for the control of the damages caused by the nematode in question [12-14]. In the various studies aiming at the analysis of $M$. enterolobii infection on fruit plants, the period between inoculation and root extraction ranged from 60 to 135 days, with 120 days being the most common interval used for this stage [11-13,15], which makes the process of evaluation quite long and costly due to the crop handling costs of the plants. The objective of this work was to evaluate the response of genotypes of P. guinense and P. guajava to the plant parasitic nematode $M$. enterolobii, in an early manner, with an inoculation period of 60 days.

\section{Materials and Methods}

The present work was conducted in the area of Phytotechnology of the Department of Agronomy of the Universidade Federal Rural de Pernambuco (UFRPE), located at $8^{\circ} 01^{\prime} 92^{\prime \prime} \mathrm{S}, 34^{\circ} 56^{\prime} 74^{\prime \prime} \mathrm{W}$. Seeds obtained from 12 genotypes of $P$. guineense from natural ocurring populations in the Pernambuco State-Brazil, 3 P. guajava genotypes obtained from domestic orchards, were planted in expanded polyethylene trays of $16 \times 8$ cells, using commercial Basaplant ${ }^{\circledR}$ substrate, alongside the commercial cultivar Paluma as a control for susceptibility. When the seedlings reached $8 \mathrm{~cm}$ in height, they were transplanted for plastic bags $20 \mathrm{~cm}$ high and $10 \mathrm{~cm}$ wide, duly identified for each genotype and conditioned in a greenhouse where they received due cultural treatment, irrigation by sprinkling and nutrient solution. The experimental design was completely randomized, corresponding to the 16 genotypes and 7 replicates. The inoculum of M. enterolobii, yielded by Embrapa Semiarido-CPATSA, was propagated in tomato (Solanum lycopersicum) which is recognized as a good host to M. enterolobii. Eggs extracted from tomato roots were counted from $1 \mathrm{~mL}$ samples on photon microscopes and the concentration of the suspension was adjusted to $1000 \mathrm{eggs} / \mathrm{mL}$ using distilled water. Soil infestation was carried out 120 days after the planting through application of 5000 eggs per plant, applied in four 2-cm deep holes around the plant stem. After 60 days, plant roots were extracted, we evaluated and passed through the process of nematode extraction according to the protocol of Hussey and Barker [16]. The host behavior in relation to the M. enterolobii infection was evaluated by examining the root system in a stereomicroscope and assessing the gall index (GI) using the International Meloidogyne Project (IMP) scale used by Taylor and Sasser [17]. The host reactions were classified according to the parameters established by Hartman and Sasser [18] according to the scale: $0=$ absence of galls or mass of eggs, $1=1-2$ galls or egg mass, $2=3-10,3=11-30,4=31-100$ and $5=$ more than 100 galls or egg mass. Plants that presented values less than or equal to 2 were considered resistant. The estimation of the number of eggs per root system was carried out with the aid of a Peters chamber, under a photonic microscope, obtaining the final population (FP). The reproductive factor (RF), according to Oostenbrink [19], was estimated by the quotient FP/ IP. The reproductive factor was compared by the Scottknott test at $5 \%$ probability. Plants with $\mathrm{RF}<1.0$ were considered resistant. The highest value obtained for the variable FR was used as a reference for the calculation of the reduction of the reproductive factor (RRF) according to the methodology of Moura and Régis [20], and classified in the following ranges: 0 to 25 =highly susceptible plant; 26 to $50=$ susceptible plant; 51 to $75=$ poorly resistant plant; 76 to $95=$ moderately resistant plant; 96 to $99=$ =resistant plant; $100=$ immune plant. For the statistical and grouping analysis, FP, FR and GI data were transformed by the square root of X, followed by Scott Knot Analysis by the Assistat Software [21].

\section{Results and Discussion}

During the 60 days of the infection period, the temperatures in the greenhouse varied between $25^{\circ} \mathrm{C}$ and $35^{\circ} \mathrm{C}$. After this period, the presence of galls in the roots of 
the inoculated plants was observed suggesting that the cycle of reproduction of the pathogen was completed without disturbances. After the infestation period and root extraction each genotype was evaluate to measure their reaction to the parasite. The cultivar Paluma chosen as a control genotype, which was previously reported to be susceptible to $M$. enterolobii [12-15,22] exhibited the highest value of galls index (GI=2.57).

Among the other genotypes, seven were considered resistant (GI $<2)$ according to this criterion (Table 1). However, observations concerning only the GI, can lead to erroneous classifications, due to its subjectivity and empiricism [23]. Taking into account the mean of the final egg population, five groups were observed, with Paluma cultivar exhibiting the highest average value of eggs (5013.75), and the two most tolerant, AR4 and AR10, with 139.29 eggs. It was observed absence of eggs some plants of genotypes AR1, AR3, AR4 and AR7, totaling six replications where no multiplication was observed. By the analysis of the reproduction factor, all genotypes evaluated, except for the control cultivar, obtained values of FR $<1$. The calculation of the index of reduction of the reproductive factor (RRF) proposed by Moura and Régis [20], compares the values of RF of each genotype with the FR value of the most affected genotype, allowing an evaluation of susceptibility proportional to the control genotype, and a more precise classification as to the degree of tolerance to phytoparasite. The RRF calculation indicated four individuals as resistant (AR1, AR3, AR4 and AR10). These four genotypes also formed the group that obtained the lowest reproduction factors and final mean population (Group e).

The correlation analysis between the FR and GI variables revealed a positive correlation between the two indices $(\mathrm{R}=0.54)$, indicating that there is a trend that genotypes exhibiting high GI values also have high RF values (Figure 1).

Several studies on the reaction of species of the Psidium genus to M. enterolobii infection demonstrated a variable response among their species to this parasite. While $P$. cattleyanum, $P$. myrtoides and $P$. acutangulum are considered immune or resistant, $P$. guajava is known to be highly susceptible $[12,13,22,24,25]$.

As observed by Carneiro et al. [26], and Castro et al. [27], the response of $P$. guineense genotypes evaluated in this study was quite variable, although all were considered resistant according to the reproduction factor. Sousa et al. [15], indicates

Table 1: Reaction of Psidium genotypes to M. enterolobii infection.

\begin{tabular}{|c|c|c|c|c|c|c|c|c|c|}
\hline Genotype & GI & \multicolumn{2}{|c|}{ FP } & RF & & RRF & GR \\
\hline AR1 & 2,29 & a & 150 & e & 0,030 & e & 97,01 & R \\
\hline AR3 & 2,14 & a & 246,43 & e & 0,049 & e & 95,08 & R \\
\hline AR4 & 1,57 & b & 139,29 & e & 0,028 & e & 97,22 & R \\
\hline AR5 & 2,43 & a & 1264,29 & c & 0,253 & c & 74,78 & PR \\
\hline AR6 & 1,43 & b & 867,86 & c & 0,174 & c & 82,69 & MR \\
\hline AR7 & 2,50 & a & 1762,50 & c & 0,353 & c & 64,85 & PR \\
\hline AR9 & 1,43 & b & 460,71 & d & 0,092 & d & 90,81 & MR \\
\hline AR10 & 1,57 & b & 139,29 & e & 0,028 & e & 97,22 & R \\
\hline AR11 & 1,86 & b & 439,29 & d & 0,088 & d & 91,24 & MR \\
\hline AR12 & 2,29 & a & 2089,29 & b & 0,418 & b & 58,33 & PR \\
\hline AR14 & 1,71 & b & 846,43 & c & 0,169 & c & 83,12 & MR \\
\hline AR15 & 2,00 & b & 1692,86 & b & 0,339 & b & 66,24 & PR \\
\hline G010 & 2,71 & a & 1082,14 & c & 0,216 & c & 78,42 & MR \\
\hline G011 & 1,86 & b & 1146,43 & c & 0,229 & c & 77,13 & MR \\
\hline G014 & 2,29 & a & 1692,86 & b & 0,339 & b & 66,24 & PR \\
\hline PALUMA & 2,57 & a & 5013,75 & a & 1,003 & a & 0,00 & - \\
\hline CV\% & 33.94 & & 30.20 & & 32.14 & & & \\
\hline
\end{tabular}

Means followed by the same superscript letter do not differ significantly $(P<0.05)$ from each other, based on the ScottKnot test. GI=Gall index, FP=Final Population, RF=Reproductive Factor, RRF=Reduction of the Reproductive Factor. GR: genotype reaction ( $R=$ Resistant, $P R=$ Poorly resistant; $M R=$ Moderately resistant). 


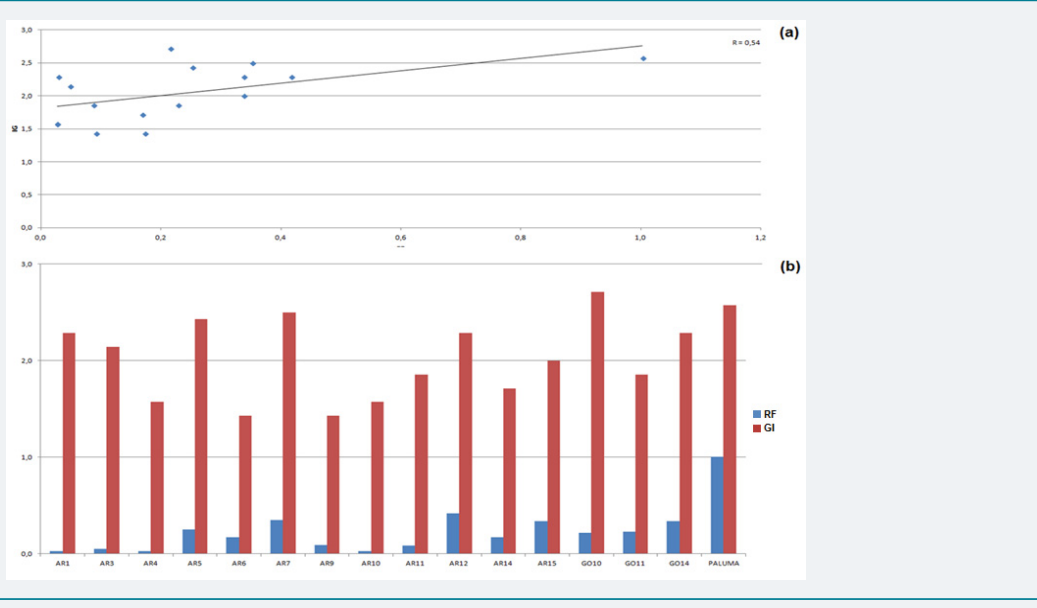

Figure 1: Correlation between the variables GI and FR (a) and individual values of the variables from each genotype (b).

that the resistance to $M$. enterolobii, observed for this species is given mainly by a developmental delay and life cycle extension. Thus, the 60-day pathogen infection period used in this study may be insufficient to accurately measure the response of these genotypes, taking into account only this criterion.

Nevertheless, the four genotypes considered resistant by the RRF calculation have great potential for use as grafts to guava trees in infested areas, due the small egg populations found in their roots. New analyzes with longer periods of infection and in field conditions in areas of occurrence of $M$. enterolobii are still necessary for the confirmation of its resistance, as well as the evaluation of their compatibility as rootstocks for commercial guava trees.

\section{Acknowledgments}

Research supported by CAPES, and UFRPE resources. R.M. Moraes Filho was supported by a Post-Doctoral Fellowship PNPD-CAPES. EA. Cavalcanti Junior was supported by a Masters Fellowship from CAPES.

\section{Author contributions}

All authors contributed equally to this study.

\section{References}

1. Pereira FM. Nachtigal JC. Melhoramento da goiabeira. In: Cultura da goiabeira: tecnologia e mercado. Rozane, D.E., Couto, F.A.d’A., Eds.; UFV: Viçosa, Brazil. 2003; 53-78.

2. Narciso N Rodríguez, Juliette Valdés, Julio A Rodríguez, Josefa B Velásquez, Domingo Rivero, et al. Genetic resources and breeding of guava (Psidium guajava L.) in Cuba. Biotecnol Apl. 2010. Ref.: https://goo.gl/eTf5e2

3. São José AR, Rebouças TNH, Dias NO, Hojo RH, et al. Cultivo de Goiabeira no Brasil. In: Primer Simpósio Internacional de La Guayaba. Memoria Aguascalientes, Aguascalientes. 2003.

4. IBGE. Produção Agrícola Municipal. 2014. http://www.sidra.ibge.gov.br.

5. Raseira MCB, Raseira A. Contribuição ao Estudo do Araçazeiro: Psidium cattleyanum. EmbrapaCPACT. 1996; 95. Ref.: https://goo.gl/p7VZh2

6. Souza RM, Nogueira MS, Lima IM, Melarato M, et al. Manejo de nematoides das galhas da goiabeira em São João da Barra (RJ) e relato de novos hospedeiros. Nematol Bras. 2006; 30: 165-169. Ref.: https://goo.gl/zPRNBQ

7. Pereira FM, Kavati R. Contribuição da pesquisa científica brasileira no desenvolvimento de algumas frutíferas de clima subtropical. Rev Bras Frutic. 2011; 108. Ref.: https://goo.gl/wqg8xj

8. Maranhão SR. Reação de indivíduos segregantes de goiabeira e araçazeiro a Meloidogyne spp. e caracterização de populações atípicas do nematoide. Dissertação Mestrado, Universidade Federal de Rural de Pernambuco, Recife. 2001. 
9. Lima IM, Dolinski C, Souza RM. Dispersão de Meloidogyne mayaguensis em goiabais de São João da Barras (RJ) e relato de novos hospedeiros dentre plantas invasoras e cultivadas. Nematologia Brasileira. 2003; 27: 257-258.

10. Guimarães LMP, Moura RM, Pedrosa EMR. Parasitismo de Meloidogyne mayaguensis em diferentes espécies botânicas. Nematologia Brasileira. 2003; 27: 139-145. Ref.: https://goo.gl/jS87ev

11. Moreira AA, Martins LSS, Musser RS, Moraes Filho RS, Maranhão W, et al. Response of Malpighia emarginata active germplasm bank accessions to Meloidogyne enterolobii parasitism. Genetics and Molecular Research. 2016; 15: 15048868. Ref.: https://goo.gl/sTBNRt

12. Scherer ARG, Carneiro APA, Mônaco MP, Moritz KC, Nakamura JC, et al. Reação de Genótipos de Psidium guajava a Meloidogyne enterolobii. Nematologia Brasileira. 2012; 36: 1-2. Ref.: https://goo.gl/f61PuL

13. Martins LSS, Musser RS, Souza AG, Resende LV, Maluf WR. Parasitismo de Meloidogyne enterolobii em espécies de Myrtaceae. Revista Brasileira de Fruticultura. 2013; 35: 477-484. Ref.: https://goo.gl/p9t3ve

14. Biazatti MA, Souza RM, Marinho CSI, Guilherme DO, Campos GS, et al. Resistência de genótipos de araçazeiros a Meloidogyne enterolobii. Ciência Rural. 2016; 46: 418-420. Ref.: https://goo.gl/TiUMTa

15. Sousa ADP, Silva EMR, Castro CUC, Cunha JMC, Ribeiro JM. Penetration, development, and reproduction of Meloidogyne enterolobii on Psidium species and induced cellular responses in the roots. Revista Brasileira de Fruticultura. 2017; 39: 453. Ref.: https://goo.gl/jXFPqz

16. Hussey, R.S.; Barker, K.R. A comparison of methods of collecting inoculated of Meloidogyne spp., including a new technique. Plant Disease Reporter. 1973; 57: 1025-1028. Ref.: https://goo.gl/4DKR9r

17. Taylor AL, Sasser JN. Biology identification and control of root-knot nematodes (Meloidogyne species). Raleigh: North Carolina State University Graphics. 1978; 111. Ref.: https://goo.gl/2ejnXA

18. Hartman KM, Sasser JN. Identification of Meloidogyne species on the basis of differential host test and perineal-pattern morphology. In: Advanced Treatise on Meloidogyne: Methodology; Barker, K.R, Carter, C.C. \& Sasser, J.N. Eds.; Raleigh NC. North Carolina State University, USA. 1985; 2: 69-77. Ref.: https://goo.gl/abRSES

19. Oostenbrink M. Major characteristic of the relation between nematodes and plants. Wageningen: Medelingen. Landbowhogeschool. 1966; 46. Ref.: https://goo.gl/RnKgif

20. Moura RM, Régis EMO. Reações de cultivares de feijoeiro comum (Phaseolus vulgaris) em relação ao parasitismo de Meloidogyne javanica e M. incognita (Nematoda: Heteroderidae). Nematol Bras. 1987; 11: 215-225.

21. Silva F de ASE, Azevedo CAV de. The Assistat Software Version 7.7 and its use in the analysis of experimental data. Afr J Agric Res. 2016; 11: 3733-3740. Ref.: https://goo.gl/wErZaE

22. Miranda GB, Souza RM, Gomes VM, Ferreira TF, Almeida AM. Avaliação de acessos de Psidium spp. quanto à resistência a Meloidogyne enterolobii. Bragantia, Campinas. 2012; 71: 52-58. Ref.: https://goo.gl/kCfKaV

23. Costa Filho JH. Coleta e reação de acessos de melancia a Meloidogyne enterolobii. Mestrado em Fitotecnia, Universidade Federal Rural do Semi-Árido, Mossoró (RN). 2012; 27: 238-241. Ref.: https://goo.gl/sL8D8q

24. Marques ML, Pimentel SJP, Tavares OCH, Veiga CFM, Berbara RLL. Hospedabilidade de diferentes espécies de plantas a meloidogyne enterolobii no Estado do Rio de Janeiro. Nematropica. 2012; 42 303-313. Ref.: https://goo.gl/1f2d4H

25. Pereira KC, Soares PLM, Santos JM dos, Batista ESP, Maldonato WJ. Desenvolvimento de cultivares de goiabeira inoculadas com Meloidogyne enterolobii. Nematropica. 2016; 46: 54-59. Ref.: https://goo.gl/BPCvs8

26. Carneiro RMDG, Cirotto PA, Silva DB, Carneiro RG. Resistance to Meloidogyne mayaguensis in Psidium spp. accessions and their grafting compatibility with $P$. guajava cv. Paluma. Fitopatologia Brasileira. 2007; 32: 281-284. Ref.: https://goo.gl/5pNBb4

27. Castro JMC, Flori JE, Santos CAF, Antunes EF. Evalution of tolerance of Psidium species to the Meloidogyne mayaguensis nematode. In: International Symposium on Guava and other Myrtaceae, Merida, Mexico. 2008; 25. Ref.: https://goo.gl/bdoq2j 